\title{
Synthesis of Transfer Ribonucleic Acids with Uridine or 2'-O-Methylribothymidine at Position 54 in Developing Dictyostelium discoideum
}

\author{
By THEODOR DINGERMANN, MICHAEL MACH AND \\ HELGA KERSTEN \\ Institut für Physiologische Chemie, Universität Erlangen-Nürnberg, Fahrstrasse 17, \\ 8520 Erlangen, Federal Republic of Germany
}

(Received 31 January 1979)

\begin{abstract}
In amoebae of Dictyostelium discoideum the ribothymidine (rT) content of tRNA is $0.9 \mathrm{~mol} \%$, but decreases progressively during development into spores. To elucidate which nucleosides replace $\mathrm{rT}$ at position 54 in developmental tRNA we have characterized 'vegetative' and 'developmental' tRNAs from the slime mould. Specific tRNAs were separated by two-dimensional gel electrophoresis. During early developmental stages, all tRNA species that could be separated by this method were newly synthesized. A new tRNA with uridine in place of $\mathrm{rT}$ and having an electrophoretic mobility similar to 'vegetative' $\mathrm{tRNA}^{\mathrm{Asn}}$ was detected during the early preaggregation stage. This 'developmental' $t R N A$ was also extracted from purified polysomes. When development proceeds from preaggregation to postaggregation, tRNAs accumulate with $2^{\prime}-O$-methylribothymidine in place of $\mathrm{rT}$. We suggest that these developmental tRNAs are important for the synthesis of specific developmental proteins.
\end{abstract}

\section{INTRODUCTION}

Eukaryotic tRNAs have been divided into four classes with respect to the nucleoside in loop IV at position 54 (numbering according to Gauss et al., 1979). Class A includes the initiator tRNAs that have an adenosine residue; class B tRNAs contain ribothymidine (rT), pseudouridine $(\forall)$ or $2^{\prime}-O$-methylribothymidine $(\mathrm{Tm})$; in class $\mathrm{C}$ tRNAs uridine $(\mathrm{U})$ is partially converted to $r T$; while in class $D$ tRNAs position 54 is completely occupied by $U$ (Roe et al., 1976). It has been suggested that the modifications of U54 in eukaryotic tRNAs are involved in regulatory mechanisms at the translational level (Roe \& Tsen, 1977).

We have recently observed that in the lower plant Acetabularia mediterranea variations occur in the U54 modification of total tRNA during development (Schmidt et al., 1977b). In further experiments we have used the slime mould Dictyostelium discoideum to study the modification of tRNA in a simple developmental system. The slime mould can be grown vegetatively as single cells in a defined medium (Watts \& Ashworth, 1970) and differentiation is induced by starvation (Loomis, 1975). After an early developmental preaggregation stage that involves signalling with pulses of cyclic AMP (Gerisch \& Malchow, 1976), the cells aggregate into mounds each containing about $10^{5}$ cells. The mounds form slugs, which subsequently differentiate into mature fruiting bodies, containing spores at the top of a vacuolized stalk. As previously reported (Dingermann et al., 1977), the amount of rT in tRNA in $D$. discoideum decreases progressively from $0.9 \mathrm{~mol} \%$ in vegetative cells to $0.5 \mathrm{~mol} \%$ in the early preaggregation stage and $0.4 \mathrm{~mol} \%$ in spores.

Dictyostelium discoideum has now been used in an attempt to elucidate the following: 0022-1287/79/0000-8585 \$02.00 (c) 1979 SGM 
(i) whether the developmental changes in U54 modification of tRNA might reflect variations in the overall distribution of class B, C and D tRNAs; (ii) whether specific developmental tRNAs are formed that are used for protein synthesis during differentiation of the amoebae. The results show a stage-specific formation of developmental tRNAs with U54 or Tm54 in place of rT. The specific 'preaggregation tRNA U54' is involved in protein synthesis.

\section{METHODS}

Chemicals. Chemicals were from the following sources: $\left[{ }^{3} \mathrm{H}\right]$ aspartic acid $\left(15 \mathrm{Ci} \mathrm{mmol}^{-1}\right),\left[{ }^{3} \mathrm{H}\right]$ threonine (2 $\left.\left.\mathrm{Ci} \mathrm{mmol}^{-1}\right),{ }^{3} \mathrm{H}\right]$ phenylalanine $\left(113 \mathrm{Ci} \mathrm{mmol}^{-1}\right)$ from New England Nuclear; $\left.{ }^{3} \mathrm{H}\right]$ asparagine $(22 \mathrm{Ci}$ $\mathrm{mmol}^{-1}$ ) from CEA-France; potassium $\left[{ }^{3} \mathrm{H}\right]$ borohydride $\left(18 \mathrm{Ci} \mathrm{mmol}^{-1}\right), S$-adenosyl-L-[Me- $\left.{ }^{2} \mathrm{H}\right]$ methionine ([Me- $\left.{ }^{3} \mathrm{H}\right] \mathrm{SAM} ; 11 \cdot 3 \mathrm{Ci} \mathrm{mmol}^{-1}$ ) and all other tritiated amino acids from Amersham Buchler, Braunschweig, Germany; alkaline phosphatase, snake-venom phosphodiesterase and RNAase $T_{3}$ from Worthington Biochemical Corp.; RNAase $\mathrm{T}_{2}$ from Sankyo, Japan; RNAase A from Boehringer; acrylamide, bisacrylamide and $N, N, N^{\prime}, N^{\prime}$-tetramethylethylenediamine (TMED) from Serva, Heidelberg, Germany. X-ray films and XR5 for fluorography were from Kodak. All other chemicals were of reagent grade. Streptomycin was a kind gift from Hormon-Chemie, München, Germany.

Organisms, growth and development. Dictyostelium discoideum, strain AX-2, was grown in axenic medium (Watts \& Ashworth, 1970) containing (per litre): Oxoid bacteriological peptone, 14.3 g; Oxoid yeast extract, $7.15 \mathrm{~g}$; maltose (Merck), $18.0 \mathrm{~g} ; \mathrm{Na}_{2} \mathrm{HPO}_{4}, 0.64 \mathrm{~g} ; \mathrm{KH}_{2} \mathrm{PO}_{4}, 0.486 \mathrm{~g}$. The pH was adjusted to 6.7. Maltose was autoclaved separately and streptomycin was added at a final concentration of $200 \mu \mathrm{g} \mathrm{ml}^{-1}$.

Vegetative growth. Cells were grown at 22 to $23^{\circ} \mathrm{C}$ in a 201 fermenter (Eschweiler, Kiel, Germany) under aeration and harvested at a cell density of $1 \times 10^{6}$ to $2 \times 10^{6}$ in a Cepa continuous flow centrifuge at $4{ }^{\circ} \mathrm{C}$.

Preaggregation stage. Cells from the vegetative growth $\left(1 \times 10^{8}\right.$ to $\left.3 \times 10^{6} \mathrm{cells} \mathrm{ml}^{-1}\right)$ were harvested, washed three times with cold phosphate buffer $\left(2 \mathrm{mM}-\mathrm{Na}_{2} \mathrm{HPO}_{4}, 14.7 \mathrm{mM}-\mathrm{KH}_{2} \mathrm{PO}_{4}, \mathrm{pH} 6 \cdot 7\right.$, containing $200 \mu \mathrm{g}$ streptomycin $\mathrm{ml}^{-1}$; subsequently referred to as $16.7 \mathrm{mM}$-phosphate buffer) and resuspended in the same buffer at $1 \times 10^{7}$ cells ml ${ }^{-1}$. After 12 to $16 \mathrm{~h}$ further incubation the cells were harvested.

Postaggregation stage. Cells $\left(1.8 \times 10^{8}\right)$ from the vegetative growth $\left(1 \times 10^{8}\right.$ to $3 \times 10^{8}$ cells ml$\left.^{-1}\right)$ were suspended in $0.2 \mathrm{ml}$ of $16.7 \mathrm{~mm}$-phosphate buffer and spread on top of three filters (Schleicher \& Schüll, 576 , diam. $9.6 \mathrm{~cm}$ ) saturated with the buffer in a Petri dish. After 10 to $12 \mathrm{~h}$ the cells formed 'Mexican Hats' and after 13 to $15 \mathrm{~h}$ they reached the culmination stage. These stages are referred to as postaggregation stages.

Escherichia coli MRE 600, which was used as source for the rT-forming enzyme, was grown in a medium containing (per litre): Bactopeptone, $10 \mathrm{~g}$; yeast extract, $5 \mathrm{~g} ; \mathrm{NaCl}, 10 \mathrm{~g}$; glucose, $1 \mathrm{~g}$. The cells were harvested during exponential growth.

Enzyme preparations. Aminoacyl-tRNA synthetases from exponentially growing cells of $D$. discoideum were prepared according to Palatnik et al. (1977) including DEAE-cellulose chromatography and ammonium sulphate precipitation. The dialysed extract was stored at $-80^{\circ} \mathrm{C}$ and was stable for at least 2 months. The protein concentration was $15 \mathrm{mg} \mathrm{ml}^{-1}$.

The crude rT-forming methyltransferase was prepared from $E$. coli MRE 600 as described by Reszelbach et al. (1977). The protein concentration of this extract was $14 \mathrm{mg} \mathrm{ml}^{-1}$.

Preparation and analysis of $t R N A$. Cells were washed twice with TMS buffer $(10 \mathrm{mM}-\mathrm{Tris} / \mathrm{HCl}, \mathrm{pH} 7 \cdot 5$, containing $10 \mathrm{mM}-\mathrm{MgCl}_{2}$ and $2 \mathrm{mM}-\mathrm{Na}_{2} \mathrm{~S}_{2} \mathrm{O}_{3}$ ) and suspended in this buffer at $0.5 \mathrm{~g}$ wet wt ml ${ }^{-1}$. An equal volume of phenol saturated with TMS buffer was added and the mixture was stirred for $1 \mathrm{~h}$ at $4{ }^{\circ} \mathrm{C}$. After centrifugation at $20000 \mathrm{~g}$ the aqueous phase was withdrawn and $2.5 \mathrm{vol}$. absolute ethanol containing $2 \%$ $(w / v)$ potassium acetate was added. The tRNA was stored in ethanol at $-20^{\circ} \mathrm{C}$. Several tRNA preparations were combined and further purified according to Rogg et al. (1969). For nucleoside analysis, about $50 A_{260}$ units of this tRNA were further purified on a Sephadex G-200 column $(90 \mathrm{~cm} \times 1 \mathrm{~cm}$ diam.). The tRNA was eluted from the column with $10 \mathrm{mM}$-Tris/ $\mathrm{HCl}, \mathrm{pH} 7 \cdot 5$, containing $200 \mathrm{mM}-\mathrm{NaCl}$ and $10 \mathrm{mM}-\mathrm{MgCl}_{2}$. The column was equilibrated with the same buffer before use. The tRNA was collected, dialysed three times for $2 \mathrm{~h}$ against 51 distilled water and precipitated with $2.5 \mathrm{vol}$. ethanol at $-20^{\circ} \mathrm{C}$. A sample $\left(1 A_{260}\right.$ unit) of purified tRNA was digested to nucleosides and analysed by ${ }^{3} \mathrm{H}$-postlabelling (Randerath et al., 1972; Randerath et al., 1974; Chia et al., 1976).

Preparation of tRNA from polysomes. Polysomes were prepared from a $600 \mathrm{ml}$ culture $\left(2 \times 10^{6} \mathrm{cells} \mathrm{ml}^{-1}\right.$ of vegetative and preaggregation cells) according to Cocucci \& Sussmann (1970) and precipitated with 2.5 vol. ethanol. The precipitate was dissolved in $3 \mathrm{ml}$ TMS buffer containing $0.5 \%(\mathrm{w} / \mathrm{v}) \mathrm{SDS}$ and stirred for $45 \mathrm{~min}$ with $3 \mathrm{ml}$ buffer-saturated phenol. After DEAE-cellulose chromatography and Sephadex G-100 chromatography the tRNA was precipitated with ethanol.

Electrophoretic separation of specific tRNAs. Two-dimensional polyacrylamide gel electrophoresis was 
carried out according to Fradin et al. (1975) with the following modifications. Slab gels of $0.8 \times 200 \times 400 \mathrm{~mm}$ were used in the first dimension and $0.8 \times 300 \times 300 \mathrm{~mm}$ in the second dimension. Samples of 0.5 to $2.5 A_{260}$ units of labelled tRNAs were separated. To identify tRNA ${ }^{\mathrm{x}}, 4$ to $5 A_{260}$ units of bulk tRNA were separated on gels of $3 \times 200 \times 400 \mathrm{~mm}$ in the first dimension and $3 \times 300 \times 300 \mathrm{~mm}$ in the second dimension. For the first dimension gel $10 \mathrm{~g}$ acrylamide and $0.4 \mathrm{~g}$ bisacrylamide were polymerized in $100 \mathrm{ml} 80 \mathrm{~mm}$-Tris buffer (adjusted to $\mathrm{pH} 8.3$ with boric acid) containing $1 \mathrm{~mm}$-EDTA and $4 \mathrm{M}$-urea. For the spacer gel $1.9 \mathrm{~g}$ acrylamide and $0.1 \mathrm{~g}$ bisacrylamide were polymerized in $35 \mathrm{ml} 8 \mathrm{mM}$-Tris/HCl buffer, $\mathrm{pH} 6 \cdot 7$, containing $4 \mathrm{M}$-urea. In both gels the concentrations of TMED and $\left(\mathrm{NH}_{4}\right)_{2} \mathrm{~S}_{2} \mathrm{O}_{8}$ were $0.05 \%(\mathrm{w} / \mathrm{v})$. The second dimension gel contained (per $100 \mathrm{ml}$ ) $20 \mathrm{~g}$ acrylamide, $1.04 \mathrm{~g}$ bisacrylamide, $80 \mathrm{~mm}$-Tris/borate, pH 8.3, $1 \mathrm{mm-EDTA}, 4 \mathrm{M}$-urea and $\left(\mathrm{NH}_{4}\right)_{2} \mathrm{~S}_{2} \mathrm{O}_{8}$ and TMED both at $0.075 \%(\mathrm{w} / \mathrm{v})$ final concentration. Electrophoresis was performed with $400 \mathrm{~V}$ (constant voltage) in the first dimension at room temperature for $30 \mathrm{~h}$ and in the second dimension at $4{ }^{\circ} \mathrm{C}$ for $75 \mathrm{~h}$.

tRNA samples were dissolved in a mixture of $60 \%(\mathrm{w} / \mathrm{v})$ sucrose, $4 \mathrm{M}$-urea, $0 \cdot 1 \mathrm{M}$-sodium acetate, pH $4 \cdot 5$, and $1 \%(\mathrm{w} / \mathrm{v})$ 'xylene-cyanol $F F^{\prime}$ ' and applied to the gel in $1.5 \mathrm{~cm}$ slots. Electrophoresis was terminated after the blue marker had reached the bottom and the gel was then cut into strips. Unlabelled tRNA served as a marker and was stained with $0.5 \%$ ethidium bromide in running buffer for $30 \mathrm{~min}$. For the second dimension, the gel strips were placed at the bottom of the chamber and embedded in $20 \%(\mathrm{w} / \mathrm{v})$ acrylamide. Electrophoresis was performed from the bottom to the top. To detect labelled tRNAs the gels were treated first with dimethyl sulphoxide/2,5-diphenyloxazole as described by Bonner \& Lasky (1974), and then stained with $0.2 \%$ methylene blue in $0.2 \mathrm{M}$-sodium acetate buffer, $\mathrm{pH} 4.5$, for 3 to $4 \mathrm{~h}$. The gels were destained under running water overnight and then dried and plated on Kodak XR-5 films for fluorography at $-80{ }^{\circ} \mathrm{C}$.

Identification of $t R N A^{\mathrm{x}}$ after electrophoresis. Spot X (containing tRNA) and a reference spot (blank) were cut from the gel and eluted with $500 \mu 10.3 \mathrm{M}-\mathrm{NaCl}$ containing $10 \mathrm{mM}-\mathrm{MgCl}_{2}, 10 \mathrm{mM}$-sodium acetate buffer, pH 4.5, and $500 \mu \mathrm{l}$ buffer-saturated phenol. After centrifugation the organic phase was extracted with $500 \mu 1$ buffer and the combined aqueous phases were precipitated with 2 vol. ethanolic potassium acetate $(2 \%)$ in the presence of $2 \cdot 2 A_{\mathbf{2 6 0}}$ units of tRNA-free rRNA. tRNA together with added rRNA was collected by centrifugation, dried in vacuo and dissolved in $220 \mu 1 \mathrm{H}_{2} \mathrm{O}$. Each $10 \mu \mathrm{l}$ of this solution was tested with one of 19 amino acids in $50 \mu \mathrm{l}$ assay mixtures containing $100 \mathrm{~mm}$-sodium cacodylate, $\mathrm{pH} 7 \cdot 5,10 \mathrm{mM}$-ATP (neutralized with $\mathrm{NaOH}$ ), $20 \mathrm{~mm}-\mathrm{MgCl}_{2}, 2 \mu \mathrm{l}{ }^{3} \mathrm{H}$-labelled amino acid and about $100 \mu \mathrm{g}$ protein of the purified extract containing tRNA synthetases. The reaction was started by adding the tRNA solution at $22^{\circ} \mathrm{C}$. After 25 min incubation each $40 \mu \mathrm{l}$ was pipetted on to a Whatman $2 \mathrm{MM}$ filter $(25 \mathrm{~mm}$ diam.) and the aminoacylated tRNA was precipitated in $10 \%(\mathrm{w} / \mathrm{v})$ cold trichloroacetic acid (TCA). After washing the filter [three times with $5 \%$ TCA, three times with ethanol, once with ethanol/ether $(1: 1, \mathrm{v} / \mathrm{v})$, and twice with ether], the tRNA was eluted from the filter for $1 \mathrm{~h}$ with $500 \mu \mathrm{l}$ Soluene/water $(9: 1, \mathrm{v} / \mathrm{v}$; Packard), dissolved in scintillant and the radioactivity was measured in a Packard liquid scintillation counter.

In vitro methylation of $t R N A$ with the $E$. coli $r T$-forming enzyme extract. The methylation reaction mixture (final volume $90 \mu \mathrm{l}$ ) contained $33 \mathrm{~mm}$-triethanolamine $/ \mathrm{HCl}, \mathrm{pH} 8 \cdot 0,5.5 \mathrm{~mm} \beta$-mercaptoethanol, $3 \cdot 3 \mathrm{~mm}$ $\mathrm{MgCl}_{2}, 48 \mu \mathrm{M}-\left[\mathrm{Me}^{3} \mathrm{H}\right] \mathrm{SAM}\left(11 \cdot 3 \mathrm{Ci} \mathrm{mmol}^{-1}\right), 0 \cdot 5 A_{280}$ units of tRNA and enzyme extract corresponding to $280 \mu \mathrm{g}$ protein. The mixture was incubated for $2.5 \mathrm{~h}$ at $37^{\circ} \mathrm{C}$. The reaction was stopped by adding $90 \mu 1$ chloroform/phenol $(1: 1, \mathrm{v} / \mathrm{v})$. After centrifugation the aqueous phase was re-extracted with $50 \mu 1$ chloroform/phenol $(1: 1, \mathrm{v} / \mathrm{v})$. After two back extractions of the combined organic phases, the pooled aqueous phases were layered on a Sephadex G-25 column $(1 \mathrm{~m} \times 1 \mathrm{~cm}$ diam. $)$ to remove salt and $\left[\mathrm{Me}^{-3}{ }^{3}\right]$ SAM. tRNA was eluted from the column with water, dried in vacuo and then subjected to polyacrylamide gel electrophoresis.

In vivo labelling of $t R N A$. During the preaggregation stage, $8 \times 10^{7}$ cells in $4 \mathrm{ml} 16.7 \mathrm{~mm}$-phosphate buffer were labelled for $12 \mathrm{~h}$ with either $2 \mathrm{mCi}\left[{ }^{3} \mathrm{H}\right]$ uridine $\left(25 \mathrm{Ci} \mathrm{mmol}^{-1}\right)$ or $3 \mathrm{mCi}\left[{ }^{3} \mathrm{H}\right]$ methionine $\left(8 \cdot 8 \mathrm{Ci} \mathrm{mmol}^{-1}\right)$.

During the postaggregation phase, the cells were labelled for $3 \mathrm{~h}$ (from the 'Mexican Hat' stage to the culmination stage) by transferring the upper of the three filters to a Petri dish containing $1 \mathrm{mCi}-\mathrm{L}-\left[\mathrm{Me}^{-}{ }^{3} \mathrm{H}\right]-$ methionine in $300 \mu \mathrm{l}$ phosphate buffer.

During vegetative growth, a $20 \mathrm{ml}$ culture $\left(1 \times 10^{6}\right.$ cells $\left.\mathrm{ml}^{-1}\right)$ was labelled with $2 \mathrm{mCi}\left[{ }^{3} \mathrm{H}\right]$ methionine $\left(8.8 \mathrm{Ci} \mathrm{mmol}^{-1}\right)$ for $18 \mathrm{~h}\left(4 \times 10^{6}\right.$ cells $\left.\mathrm{ml}^{-1}\right)$.

$M e-{ }^{3} \mathrm{H}$-labelled tRNAs were digested to nucleosides and analysed as described by Rogg et al. (1976). 


\section{RESULTS}

\section{Separation of specific $t R N A s$}

Two-dimensional gel electrophoresis was used in preference to RPC-5 column chromatography because it permitted the separation of tRNAs into several species in a single step. Bulk tRNAs were prepared from vegetative cells and from cells starved for $12 \mathrm{~h}$ in phosphate buffer (preaggregation stage). The nucleoside compositions of both tRNA preparations were determined by ${ }^{3} \mathrm{H}$-postlabelling analysis. In accordance with our previous findings (Dingermann et al., 1977), the rT content of vegetative tRNA was $0.9 \pm 0.09 \mathrm{~mol} \%$ and that of preaggregation tRNA was $0.55 \pm 0.05 \mathrm{~mol} \%$ (the standard deviation was calculated from six chromatographic analyses). Each preparation was separated by two-dimensional electrophoresis. The patterns of specific tRNAs were almost the same for 'vegetative' tRNA and 'preaggregation' tRNA. A typical electrophoretic pattern of tRNAs from vegetative cells is shown in Fig. 1. About 45 tRNAs were resolved as separate spots. Identical electrophoretic patterns were obtained in repeated experiments.

\section{$t R N A$ synthesis during development}

When vegetative cells are starved by suspending them in phosphate buffer they stop growing and develop to the preaggregation stage at which the amoebae can be kept for about 12 to $18 \mathrm{~h}$ at $22^{\circ} \mathrm{C}$ provided that aeration is adequate. To discover which tRNAs were synthesized and methylated during early development, vegetative cells were harvested, washed and incubated for $12 \mathrm{~h}$ in buffer containing $\left[{ }^{3} \mathrm{H}\right]$ uridine or $\mathrm{L}-\left[\mathrm{Me}^{-}{ }^{3} \mathrm{H}\right]$ methionine. The tRNAs were prepared from the labelled cells and separated by electrophoresis. It is evident that during preaggregation almost all tRNA species that can be separated by this method are newly synthesized (Fig. $2 a, b$ ). The radioactivity patterns were identical to the patterns obtained after staining the gel with methylene blue.

\section{Detection of specific U54-containing $t R N A s$}

In eukaryotic class $C$ tRNAs, $r T$ in position 54 has been partly replaced by U. The U54 residue can be converted to rT by the $E$. coli tRNA (uracil-5)-methyltransferase and $S$ adenosyl-L-methionine. tRNAs of class $D$ in which $\mathrm{rT}$ has been fully replaced by $U$ can also be methylated by this specific enzyme, but at a much lower rate than class C tRNAs (Roe \& Tsen, 1977).

To detect the tRNA species with U54 we methylated bulk tRNA from both stages with $\left[M e-{ }^{3} \mathrm{H}\right] \mathrm{SAM}$ and the $E$. coli methyltransferase. Only a slight increase was observed in the overall U54 methylation of preaggregation tRNA as compared with that of vegetative tRNA (results not shown).

The tRNAs treated with the rT-forming enzyme were separated by electrophoresis. In vegetative tRNA, several species in which a U54 was methylated to rT were present. In preaggregation tRNA, a new tRNA with U54 methylated to rT was detected in repeated experiments (Fig. 3). Elution of the tRNA from this spot followed by enzymic digestion and nucleoside analysis revealed only rT (Fig. 4), indicating that the new 'developmental' tRNA had U in place of rT.

The developmental tRNA had the same electrophoretic mobility as vegetative RNA $^{\mathbf{x}}$ in the schematic representation of Fig. 1(b). To identify the tRNA(s) present in this spot, $4 A_{260}$ units of total tRNA were separated on a gel. Under optimal conditions the eluted tRNA from spot X contained on average $0.1 A_{260}$ units. The eluate was divided into 20 portions to test the amino acid acceptance for each of 19 amino acids. Under these conditions an assay mixture contained less than $0.005 A_{260}$ units of tRNA. The amino acids in the acceptor assay were therefore used undiluted at the highest available specific activity. From each gel, three reference spots were also eluted and treated in the same way as the sample. The experiment was repeated three times. 


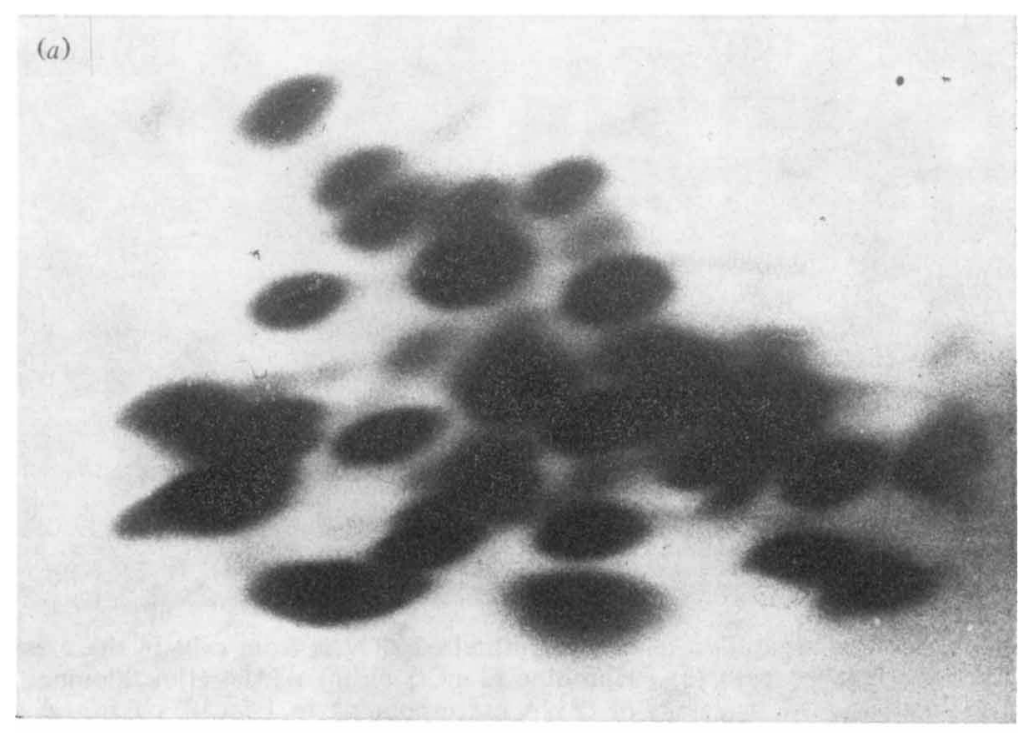

(b)

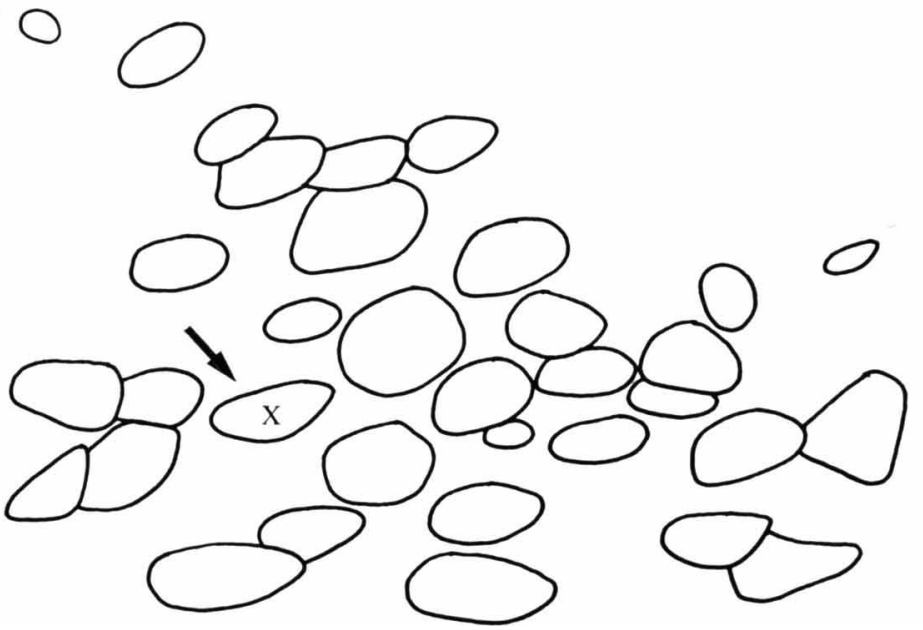

Fig. 1. Pattern of $D$. discoideum tRNA after two-dimensional polyacrylamide gel electrophoresis. (a) One $A_{260}$ unit of bulk tRNA was applied to the gel and electrophoresis done as described in Methods. The gel was stained with $0.5 \%$ ethidium bromide in running buffer for 3 min. $(b)$ Schematic representation of the electrophoretic separation of specific tRNAs. Electrophoresis was from right to left in the first dimension and from bottom to top in the second dimension. Spot X, indicated by the arrow, contains tRNA ${ }^{A n n}$ (see Table 1).

In all three cases the tRNA from spot $X$ accepted only asparagine; the results for the other 18 amino acids were found to be identical with that of a corresponding blank within the calculated standard deviation (Table 1). We therefore suggest that the tRNA in question is a tRNA ${ }^{A s a}$.

To elucidate whether the developmental tRNA U54 was used for protein synthesis, we prepared polysomes from vegetative and preaggregation cells. tRNAs were extracted from the polysomes, methylated with $\left[M e-{ }^{3} \mathrm{H}\right] \mathrm{SAM}$ and the rT-forming enzyme from $E$. coli and separated by electrophoresis. The specific developmental tRNA U54 was found to be present at polysomes, thus indicating that it is involved in protein synthesis (Fig. 5). 

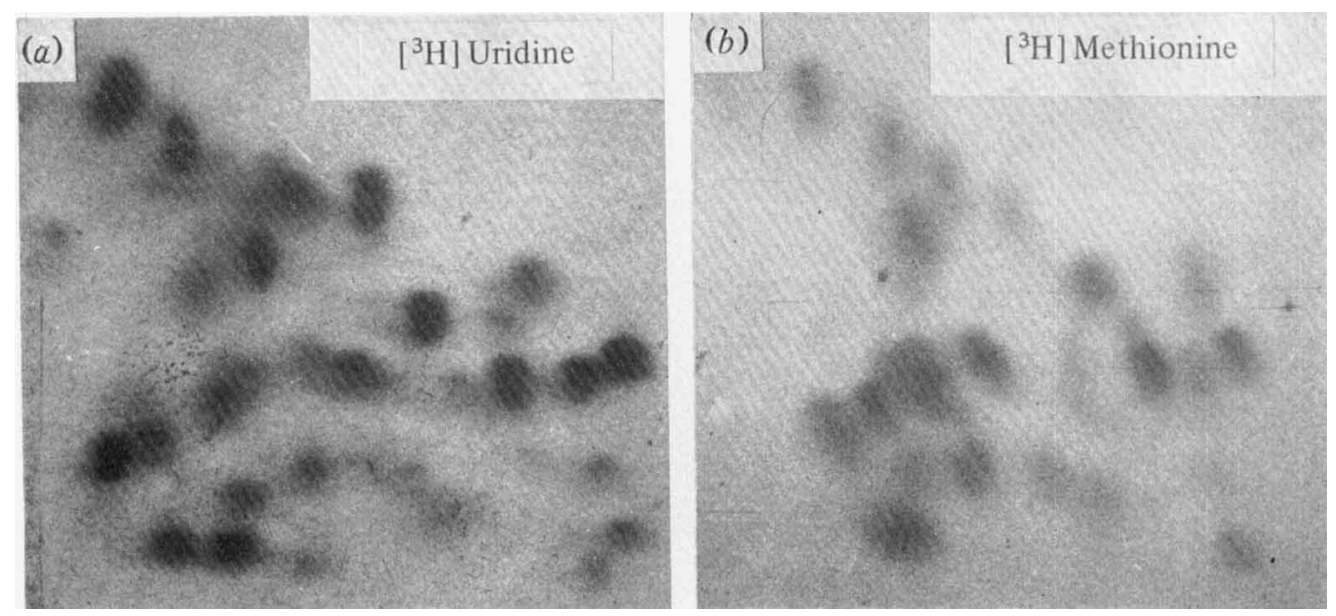

Fig. 2. Electrophoretic separation of newly synthesized tRNAs from cells in the preaggregation stage. Cells were labelled with $(a)\left[{ }^{3} \mathrm{H}\right]$ uridine $(2 \mathrm{mCi})$ or $(b) \mathrm{L}-\left[\mathrm{Me}-{ }^{3} \mathrm{H}\right]$ methionine $(3 \mathrm{mCi})$ as described in Methods; $2.5 A_{260}$ units of tRNA corresponding to $1.7 \times 10^{5}$ c.p.m. (a) or $2.4 A_{260}$ units of tRNA with $1 \times 10^{5}$ c.p.m. $(b)$ were separated. The electropherograms were treated with scintillator, stained with methylene blue, dried and exposed for fluorography for $10 \mathrm{~d}$ at $-80^{\circ} \mathrm{C}$.
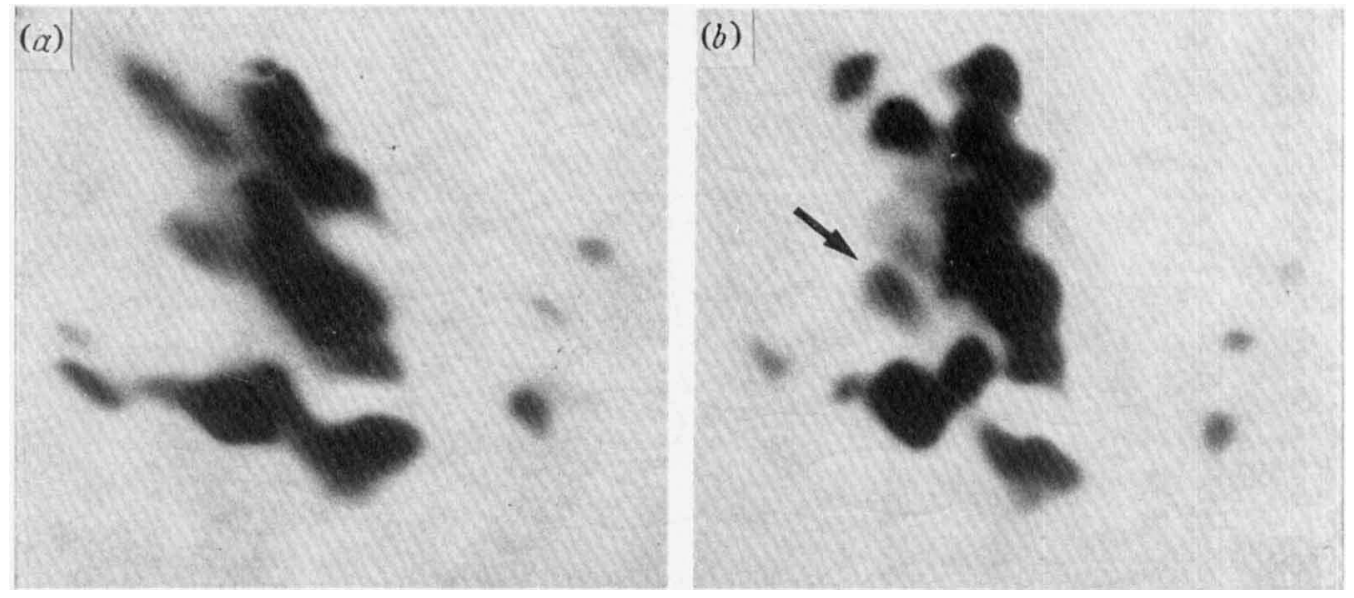

Fig. 3. Electrophoretic patterns of tRNAs U54, detected by acceptance of methyl groups from $\left[M e-{ }^{3} \mathrm{H}\right] \mathrm{SAM}$ with the rT-forming enzyme from $E$. coli: $(a)$ vegetative stage; $(b)$ preaggregation stage. One $A_{260}$ unit of tRNA was methylated as described in Methods; $1.8 \times 10^{5}$ c.p.m. of 'vegetative' tRNA and $1.9 \times 10^{5}$ c.p.m. of 'developmental' tRNA were applied to the gels. The arrow in $b$ indicates a newly synthesized developmental tRNA with U54 in place of rT.

\section{Formation of $t R N A$ Tm54 during development}

In rat liver an enzyme is present that converts rT54 to $2^{\prime}-O$-methylribothymidine, Tm (Gross et al., 1974). The previously observed decrease of rT in developmental tRNA (Dingermann et al., 1977) might imply that in certain tRNAs rT is converted to Tm or that new tRNAs are formed with Tm in place of $\mathrm{rT}$. To test this hypothesis, cells were labelled during vegetative growth, preaggregation and postaggregation with $\left[{ }^{3} \mathrm{H}\right]$ methionine and tRNA was isolated and hydrolysed to nucleosides. The nucleoside analysis of Rogg et al. (1976) permits the simultaneous detection of rT and Tm in a tRNA hydrolysate. The analysis of methyllabelled nucleosides revealed that labelled Tm was absent from vegetative tRNA. Small amounts of Tm occurred in preaggregation tRNA. During postaggregation, between 


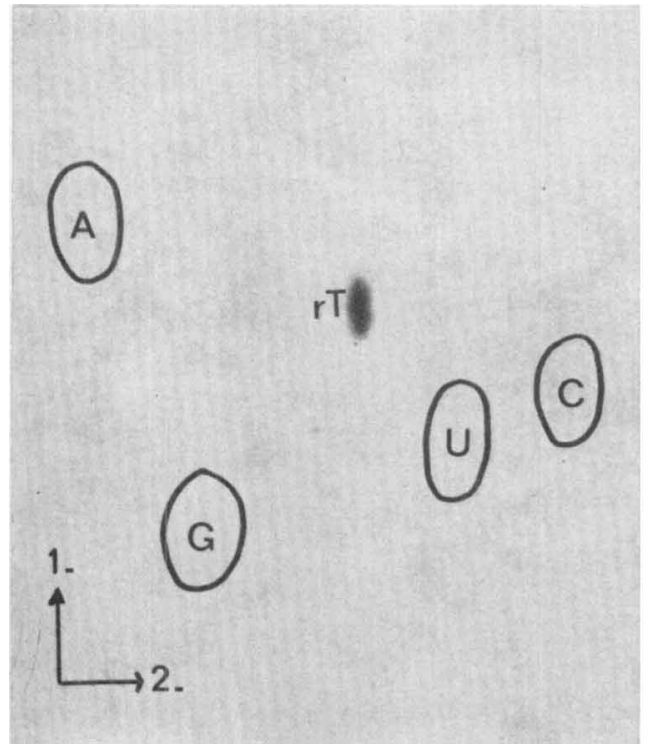

Fig. 4

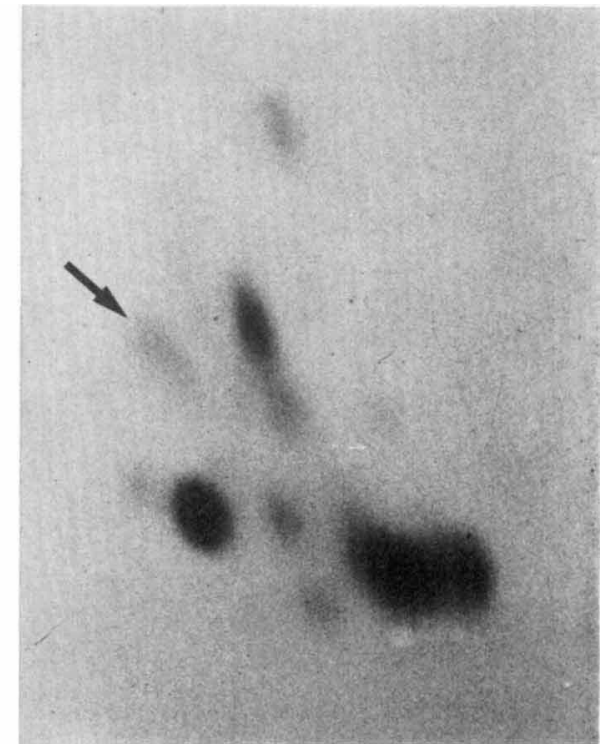

Fig. 5

Fig. 4. Product analysis of the specific 'developmental' tRNA after in vitro methylation. In vitro methylated tRNA from spot X was eluted, $1 A_{260}$ unit of carrier tRNA was added and the tRNAs were digested to nucleosides. These were separated by thin-layer chromatography with the solvent systems described by Rogg et al. (1976).

Fig. 5. Electrophoretic pattern of 'preaggregation' polysomal tRNAs U54. Bulk tRNA was extracted from purified polysomes and methylated in vitro with $\left[\mathrm{Me}-{ }^{3} \mathrm{H}\right] \mathrm{SAM}$ and the rT-forming E. coli enzyme (see Methods).

\section{Table 1. Identification of the specific $t R N A^{\mathrm{x}}$ after electrophoresis}

Three blanks and spot X (containing tRNA) were cut out from a preparative gel on which $4 A_{260}$ units of bulk tRNA had been separated. The tRNA ${ }^{\mathbf{x}}$ and three blanks were eluted and each eluate divided into 20 portions. Each portion was tested for amino acid acceptance with $19{ }^{3} \mathrm{H}$-labelled amino acids. The experiment was repeated three times. Only Asn was accepted by the tRNA of spot $X$. The values for all other amino acids were in the range of the standard deviation of the mean value of the blank.

\section{${ }^{3} \mathrm{H}$-labelled amino acid}

Ala

Arg

Asn

Asp

Glu

Gln

Gly

His

Ile

Leu

Lys

Met

Phe

Pro

Ser

Thr

Trp

Tyr

Val

$$
\begin{gathered}
\text { Specific } \\
\text { activity } \\
\left(\mathrm{Ci} \mathrm{mmol}^{-1}\right)
\end{gathered}
$$$$
37
$$$$
8
$$$$
22
$$$$
15
$$$$
28
$$$$
20
$$$$
23
$$$$
43
$$$$
28
$$$$
50
$$$$
90
$$$$
8
$$

\section{Radioactivity (c.p.m.)}

$\begin{array}{rr}\text { Blank } & \text { Spot X } \\ 600 \pm 200 & 1076 \\ 723 \pm 294 & 750 \\ 2617 \pm 748 & 6850 \\ 1239 \pm 295 & 1535 \\ 2990 \pm 392 & 3708 \\ 3327 \pm 563 & 3490 \\ 3474 \pm 881 & 3300 \\ 1163 \pm 402 & 1260 \\ 380 \pm 199 & 334 \\ 805 \pm 321 & 904 \\ 10542 \pm 2484 & 13320 \\ 5329 \pm 991 & 5231 \\ 940 \pm 279 & 1129 \\ 1232 \pm 357 & 1446 \\ 1632 \pm 420 & 2083 \\ 348 \pm 180 & 264 \\ 3307 \pm 833 & 3777 \\ 1384 \pm 508 & 1593 \\ 809 \pm 237 & 792\end{array}$



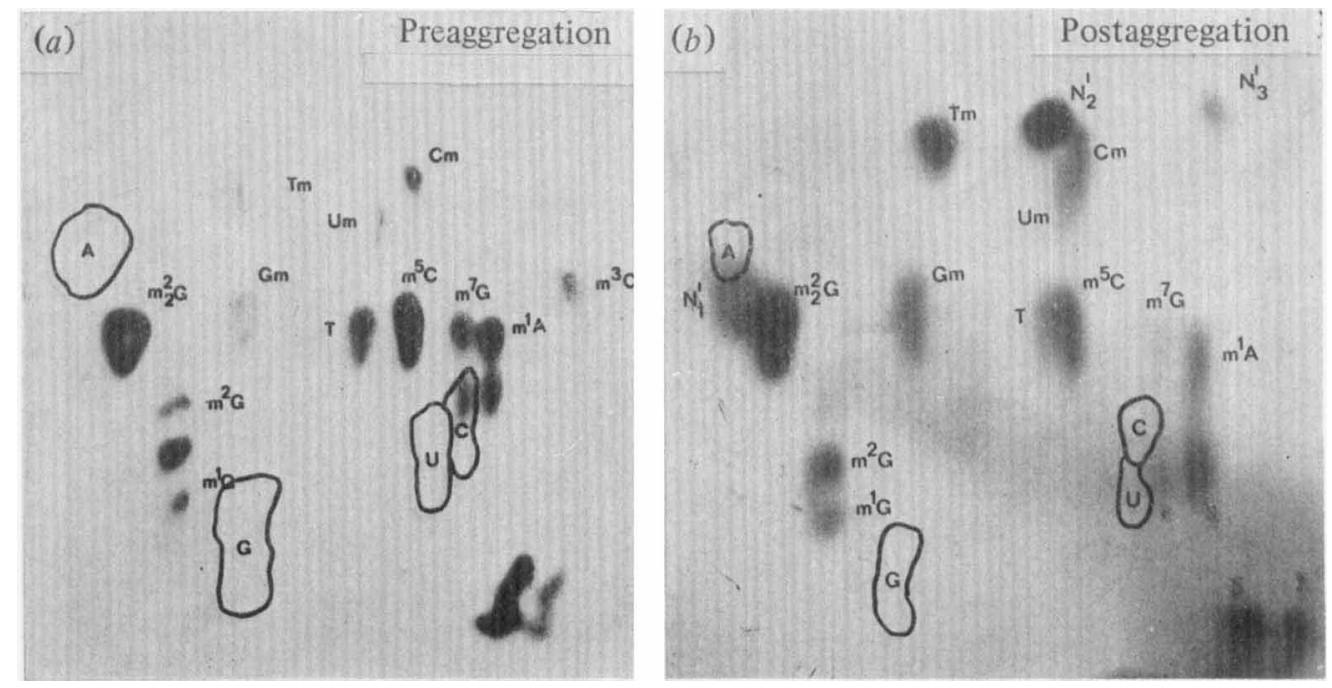

Fig. 6. Patterns of methyl-labelled nucleosides from developmental tRNAs after two-dimensional thin-layer chromatography. tRNA nucleosides from $\left[{ }^{3} \mathrm{H}\right]$ methionine-labelled cells in $(a)$ preaggregation stage and $(b)$ postaggregation stage. About $3 A_{260}$ units of tRNA with $1.2 \times 10^{5}$ c.p.m. $(a)$ and $1.5 A_{260}$ units of tRNA with $1.6 \times 10^{5}$ c.p.m. $(b)$ were digested with RNAase A, alkaline phosphatase, snake-venom phosphodiesterase and RNAase $T_{1}$. The nucleosides were separated according to Rogg et al. (1976).

formation of the 'Mexican Hat' and culmination, the amount of labelled Tm relative to labelled rT markedly increased (Fig. $6 a, b$ ).

\section{DISCUSSION}

Almost all prokaryotic and a great number of eukaryotic tRNAs that have been sequenced have the modified nucleoside $\mathrm{rT}$ at position 54 in a common sequence TUCG in loop IV of tRNA. The methylation of U54 to rT seems to play an important role in tRNA evolution because $\mathrm{rT}$ occurs only once in the tRNA molecule and always occupies the same position. In addition, $\mathrm{rT}$ is the unique methylated base for which two independent biosynthetic pathways have been evolved: the SAM-dependent pathway in Gram-negative bacteria and in eukaryotes (Mandel \& Borek, 1963) and the tetrahydrofolate-dependent pathway in most Gram-positive micro-organisms (Schmidt et al., 1977a). As has been shown for E. coli, the methylation of $\mathrm{U}$ to $\mathrm{rT}$ in this position in tRNAs gives the cell a survival advantage (Björk \& Neidhardt, 1974).

Acetabularia mediterranea and $D$. discoideum have their greatest amount of $\mathrm{rT}(0.9 \mathrm{~mol} \%)$ in tRNA during vegetative growth stages when almost all proteins are synthesized at a high rate. During development the overall amount of rT in total tRNA is much lower (Schmidt et al., 1977b; Dingermann et al., 1977). Here we show that the observed decrease in the rT content of tRNA during the development of $D$. discoideum can be explained by an accumulation of tRNAs that have $U$ or Tm in position 54 . When vegetative amoebae stop growing and development ensues tRNAs are synthesized and methylated.

The new specific preaggregation tRNA U54 identified had almost the same electrophoretic mobility as vegetative tRNA ${ }^{\mathrm{Asn}}$ and might be identical with one of the tRNA ${ }^{\mathrm{Asn}}$ isoacceptors observed by Palatnik et al. (1977). These authors speculate that during early development an incompletely modified species of $\operatorname{tRNA}^{\mathrm{Asn}}$ occurs, with $\mathrm{G}$ in place of the modified guanosine derivative $Q$ in the first position of the anticodon. Rat liver tRNA ${ }^{\text {An }}$ has been sequenced recently and shown to contain the modified nucleoside $Q$ (Chen \& Roe, 1978).

In our experiments the developmental tRNA U54 was detected by the capacity to accept 
methyl groups from $S$-adenosylmethionine by the rT-forming enzyme from $E$. coli. The preaggregation tRNA thus belongs either to class $C$ or class $D$ according to the classification of Roe et al. (1976) (see Introduction). Since class D tRNAs whose $r T$ has been fully replaced by U54 are poor substrates for the E. coli rT-forming enzyme (Roe \& Tsen, 1977) it is possible that further specific developmental tRNAs U54 are formed which cannot be detected by in vitro methylation.

The accumulation of tRNAs Tm during postaggregation might be the result of either (i) the $\mathrm{rT}$ residue in specific tRNAs that are present during vegetative growth and development becoming hypermethylated by a specific developmental tRNA (ribose-2' $-O$-methyltransferase) or (ii) synthesis of specific developmental tRNAs in which rT is methylated by a pre-existing enzyme. We conclude from our results that the overall distribution of tRNAs with U54 or rT54 or Tm54 (class B, C and D tRNAs) is changed when the slime mould starts to aggregate and finally forms spores.

The question arises as to whether developmental tRNAs with U54 or Tm54 are involved in protein synthesis or whether they serve other regulatory functions. The specific preaggregation tRNA U54 from $D$. discoideum was found to be present in purified polysomal fractions. This result strongly suggests that the developmental tRNA is used for protein synthesis. Our results therefore support an early proposal made by Sharma \& Borek (1970) who analysed tRNA methylation in $D$. discoideum. They observed the occurrence of inhibitors of tRNA methyltransferases and suggested that tRNA methylation may serve a regulatory function in producing specific tRNA forms for new protein synthesis or by rendering some tRNA forms non-functional for old protein synthesis.

The nucleoside modification at position 54 of tRNA might have a regulatory function in protein synthesis. The following observations support this hypothesis: (i) prokaryotic and eukaryotic counterparts of specific tRNAs with U54 in place of rT function with an altered efficiency in in vitro protein synthesis (Albani et al., 1978; Marcu \& Dudock, 1976; Roe \& Tsen, 1977); (ii) during codon-anticodon recognition, aminoacyl tRNAs are bound to the ribosomal A-site, probably by interaction of the $\mathrm{T} U \mathrm{C}$ or an analogous sequence with a complementary sequence of 5S rRNA in prokaryotes or 5.8S rRNA in eukaryotes (Erdmann, 1976, and references therein); (iii) mRNA seems to induce a conformational change in aminoacyl-tRNA exposing the trinucleotide sequence TVC for binding to the ribosome (Schwarz et al., 1974). Thus the nucleoside present in position 54 of a given tRNA species might influence codon-anticodon recognition and mRNA selection at the ribosome.

We thank Dr Walter Kersten for encouragement in this work and for stimulating discussions. We are indebted to Drs G. Dirheimer, H. Feldmann and G. Gerisch for helpful advice. We thank Mrs S. Noeth for preparing the manuscript. We acknowledge the support by the Deutsche Forschungsgemeinschaft, grant Ke 98/14 and the Fonds der Chemischen Industrie.

\section{REFERENCES}

Albani, M., Hoburg, A., Kersten, H., Wurmbach, P. \& Nierhaus, K. H. (1978). On the interaction of m5U deficient tRNA ${ }^{\text {Phe }}$ and tRNA ${ }^{\text {Lys }}$ with ribosomes. 12th FEBS Meoting, Dresden, Abstract No. 1658.

Buörk, G. R. \& Neldhardt, F. C. (1974). Physiological and biochemical studies on the function of 5-methyluridine in the transfer ribonucleic acid of Escherichia coli. Journal of Bacteriology 124, 99-111.

Bonner, W. M. \& LAskey, R. A. (1974). A film detection method for tritium-labelled proteins and nucleic acids in polyacrylamide gels. European Journal of Biochemistry 46, 83-88.
Chen, E. Y. \& Roe, B. A. (1978). The nucleotide sequence of rat liver tRNA ${ }^{\mathrm{Asn}}$. Biochemical and Biophysical Research Communications 82, 235-246.

Chia, L. S. Y., Morris, P., Randerath, K. \& RANDERATH, E. (1976). Base composition studies on mitochondrial 4S RNA from rat liver and Morris hepatomas $5132 \mathrm{D}$ and 7777 . Biochimica et biophysica acta 425, 49-62.

Cocucci, S. \& Sussman, M. (1970). RNA in cytoplasmic and nuclear fractions of cellular slime mold amebas. Journal of Cellular Biology 45, 399-407. Dingermann, Th., Schmid, W. \& Kersten, $H$. (1977). Modified bases in tRNA of Dictyostelium discoideum: alterations in the ribothymidine con- 
tent during development. FEBS Letters 80, 205208.

ErdmanN, V. A. (1976). Structure and function of 5S and 5.8S RNA. Progress in Nucleic Acid Research and Molecular Biology 18, 45-90.

FradiN, A., GruHL, H. \& FeldmanN, H. (1975). Mapping of yeast tRNAs by two-dimensional electrophoresis on polyacrylamide gels. FEBS Letters 50, 185-189.

Gauss, D. H., Grüter, F. \& Sprinzl, M. (1979). Compilation of tRNA sequences. Nucleic Acids Research 6, r1-r44.

GerisCh, G. \& MALChOW, D. (1976). AMP receptors and the control of cell aggregation in Dictyostelium. Advances in Cyclic Nucleotide Research 7, 49-68.

Gross, H. J., Simsek, M., Raba, M., Limburg, K., HECKMAN, J. \& RaJBhandaRY, U. L. (1974). 2'-O-Methylribothymidine: a component of rabbit liver lysine. Nucleic Acids Research 1, 35-43.

Loomis, W. F. (1975). Dictyostelium discoideum, a Developmental System. New York: Academic Press.

MANDEL, L. R. \& BorEK, E. (1963). The biosynthesis of methylated bases in ribonucleic acid. Biochemistry 2, 555-560.

MARCU, K. B. \& Dudock, B. S. (1976). Effect of ribothymidine in specific eukaryotic tRNAs on their efficiency in in vitro protein synthesis. Nature, London 261, 159-162.

Palatnik, C. M., Katz, E. R. \& Brenner, M. (1977). Isolation and characterization of transfer RNAs from Dictyostelium discoideum during growth and development. Journal of Biological Chemistry 252, 694-703.

RANDERATH, E., YU, C.-T. \& RANDERATH, K. (1972). Base analysis of ribopolynucleotides by chemical tritium labeling. Analytical Biochemistry 48, 172-198.

Randerath, K., Randerath, E., Chia, L. S. Y. \& NowAK, B. J. (1974). Base analysis of ribopolynucleotides by chemical tritium labeling. Analytical Biochemistry 59, 263-271.

Reszelbach, R., Greenberg, R., Pirtle, R., Prasad, R. \& Dudock, B. (1977). Isolation and comparison of ribothymidine-lacking tRNAs of fetal, newborn and adult bovine tissues. Biochimica et biophysica acta 475, 383-392.

RoE, B. A. \& TSEN, H.-Y. (1977). Role of ribothymidine in mammalian tRNA ${ }^{\text {Phe }}$. Proceedings of the National Academy of Sciences of the United States of America 74, 3696-3700.

Roe, B. A., ChEN, E. Y. \& TsEN, H.-Y. (1976). Studies on the ribothymidine content of specific rat and human tRNAs: a postulated role for 5methylcytosine in the regulation of ribothymidine biosynthesis. Biochemical and Biophysical Research Communications 68, 1339-1347.

RogG, H., Wehrli, W. \& Staehelin, M. (1969). Isolation of mammalian transfer-RNA. Biochimica et biophysica acta 195, 13-15.

Rogg, H., Brambilla, R., Keith, G. \& Staehelin, M. (1976). An improved method for separation and quantitation of modified nucleosides of transfer RNA. Nucleic Acids Research 3, 285-295.

Schmidt, W., ARnold, H. H. \& Kersten, H. (1977a). Tetrahydrofolate-dependent biosynthesis of ribothymidine in transfer ribonucleic acids of gram-positive bacteria. Journal of Bacteriology 129, 15-21.

Schmidt, W., Kersten, H. \& Schweiger, H. J. (1977b). Base analysis of tRNA from Acetabularia mediterranea. In Progress in Acetabularia Research, pp. 39-43. Edited by C. L. F. Woodcock. New York: Academic Press.

Schwarz, U., LÜHRMANN, R. \& Gassen, H. G. (1974). On the mRNA induced conformational change of AA-tRNA exposing the T-U-C-G sequence for binding to the 50S ribosomal subunit. Biochemical and Biophysical Research Communications 56, 807-814.

Sharma, O. K. \& BoreK, E. (1970). Inhibitor of transfer ribonucleic acid methylases in the differentiating slime mold Dictyostelium discoideum. Journal of Bacteriology 101, 705-708.

WATTS, D. J. \& Ashworth, J. M. (1970). Growth of myxamoebae of the cellular slime mould Dictyostelium discoideum in axenic culture. Biochemical Journal 119, 171-174. 